\title{
KAJIAN HISTORIS PENGEMBANGAN PENDIDIKAN ISLAM DI INDONESIA
}

\author{
Oleh: \\ Azkia Muharom Albantani \\ Universitas Islam Negeri (UIN) Syarif Hidayatullah Jakarta \\ E-mail: azki@uinjkt.ac.id
}

\begin{abstract}
Abstrak
Artikel ini menjelaskan perjalanan panjang suka dan duka yang dialami pendidikan Islam di Indonesia, mulai dari munculnya pondok pesantren, sekolah Islam, dan madrasah. Asal usul lembaga-lembaga tersebut pun tak luput dari pembahasan di dalam artikel ini sehingga dapat diketahui karakteristik masing-masing lembaga pendidikan Islam. Ketiga lembaga tersebut memiliki andil yang sangat besar dalam pengembangan pendidikan Islam di Indonesia. Kebijakan pemerintah pusat yang berkaitan dengan pendidikan juga memiliki pengaruh yang sangat besar dalam perkembangan ketiga lembaga tersebut. Penulis pun sekilas membahas beberapa contoh dari pengelolaan lembaga pendidikan Islam saat ini. Dalam rangka mewujudkan lembaga pendidikan Islam yang bermutu, berbagai lembaga tersebut harus tetap mempertahankan nilai-nilai khas yang dimiliki dengan tetap menyelenggarakan pendidikan Islam sesuai dengan acuan Standar Nasional Pendidikan yang menjadi pedoman utama pendidikan nasional.
\end{abstract}

Kata Kunci: pendidikan Islam, kajian historis, kebijakan pendidikan Islam

\section{Pendahuluan}

Pendidikan Islam mulai muncul dan berkembang di Indonesia sejak Islam masuk dibawa oleh kaum sufi atau pedagang dari Timur Tengah, yang kemudian hidup membaur dengan penduduk lokal. Ketika membaur itulah berlangsung transmisi Islam yang diterima oleh penduduk lokal melalui proses penyesuaian dengan tata-cara hidup dan tradisi yang telah mereka jalankan sebelumnya. Pendidikan Islam, kemudian, menjadi sebuah upaya terstruktur yang dijalankan umat dalam rangka mewujudkan transmisi ilmu pengetahuan keislaman di lembaga-lembaga pendidikan.

Di Indonesia, masyarakat disuguhkan kepada lembaga pendidikan yang sangat variatif, di antaranya pondok pesantren, madrasah, dan sekolah. Ketiga lembaga ini sama-sama memberikan kontribusi dalam mencerdaskan kehidupan bangsa dan memberdayakan masyarakat. Adapun pondok pesantren, madrasah, dan sekolah 
memiliki tujuan yang sama, namun berbeda dalam segi pengelolaannya dan memiliki ciri khas masing-masing. ${ }^{1}$

Ketiga lembaga ini terkadang mendapatkan pandangan negatif dari berbagai kalangan masyarakat. Sampai saat ini, pondok pesantren terkadang memperoleh pandangan negatif masyarakat, lembaga pendidikan kolot, kumuh, kampungan, tidak maju, dan lembaga akhirat. Hal tersebut menjadikan masyarakat ragu untuk mendaftarkan anak-anaknya di pondok pesantren, padahal stigma tersebut hanya benarbenar terjadi dalam jumlah kecil Pondok Pesantren yang ada di Indonesia.

Sekolah dan madrasah juga terkadang mendapat stigma negatif masyarakat. Sekolah sering mendapatkan pandangan memiliki kualitas tidak jelas, berpikir mundur, dan banyak beban pelajaran. Berbagai pandangan negatif tersebut mestinya menjadi tantangan dan tugas para pendidik termasuk pemerintah untuk memberikan solusi dalam rangka menghindari sikap apriori masyrakat terhadap lembaga pendidikan yang ada (pondok pesantren, madrasah, dan sekolah).

\section{Pondok Pesantren}

Terdapat dua pandangan mengenai asal-usul pondok pesantren, Karel A. Steenbrink berpandangan bahwa pendidikan pondok pesantren berasal dari India dan masyarakat Hindu apabila diperhatikan dari segi bentuk dan sistemnya. Sebelum proses penyebaran Islam di Indonesia, sistem tersebut telah digunakan untuk kegiatan pendidikan dan pengajaran agama Hindu di Jawa. Kemudian sistem tersebut diambil alih oleh Islam setelah masuk dan banyak tersebar di Pulau Jawa. Sedangkan Mahmud Yunus berpendapat bahwa asal-usul pendidikan pondok pesantren berasal dari sistem pendidikan di Baghdad. ${ }^{2}$

Dari segi bahasa, Pondok pesantren merupakan gabungan dari dua kata, Pondok dan pesantren. Istilah pondok berasal dari Bahasa Arab funduq, memiliki makna hotel atau asrama, ${ }^{3}$ Sedangkan istilah Pesantren berasal dari kata santri, yang dengan awalan $P e$ di depan dan akhiran an berarti tempat tinggal para santri. Adapun Profesor Johns berpendapat bahwa santri berasal dari bahasa Tamil, yaitu guru mengaji,

${ }^{1}$ Anzar Abdullah. "Pendidikan Islam Sepanjang Sejarah: Sebuah Kajian Politik Pendidikan di Indonesia". Susurgalur Vol. 1 No. 2, 2013, hal. 213.

2 Karel A. Steenbrink, Pesantren, Madrasah, Sekolah, Pendidikan Islam dalam Kurun Modern, Jakarta : LP3ES, 1994, hal. 22.

3 Zamaksyari Dhofier, Tradisi Pesantren Studi Tentang Pandangan Hidup Kyai, Jakarta : LP3ES, Cet.III, 1982, hal.18. 
sedangkan menurut C.C. Berg kata Santri berasal dari bahasa India, Shastri yaitu orang yang memahami buku-buku suci Agama Hindu. Kata Shastri berasal dari kata shastra yang berarti buku-buku suci, buku-buku agama atau buku-buku tentang ilmu Pengetahuan. ${ }^{4}$ Dengan demikian, Pondok pesantren merupakan lembaga pendidikan Islam yang tumbuh dan diakui masyarakat sekitar dengan menggunakan sistem asrama yang menjadi tempat para santri menerima pendidikan agama melalui sistem pengajian atau madrasah yang berada di bawah kedaulatan kiai dengan karakteristik kharismatik dan independen dalam segala hal.

Pesantren dapat dimaknai sebagai suatu tempat tinggal bagi para santri untuk mempelajari agama Islam. ${ }^{5}$ Menurut Peraturan Pemerintah Republik Indonesia Nomor 55 Tahun 2007 Pasal 1 Ayat 4 pesantren atau pondok pesantren adalah lembaga pendidikan keagamaan Islam berbasis masyarakat yang menyelenggarakan pendidikan diniyah atau secara terpadu dengan jenis pendidikan lainnya. ${ }^{6}$ Pondok Pesantren juga dapat dipahami sebagai lembaga pendidikan Islam yang memiliki ciri khas asrama santri dengan bimbingan kyai dan ustadz dalam mendalami ilmu agama. Terdapat 5 (lima) unsur penting dalam pondok pesantren, yaitu kyai (ustadz), pondok (asrama), masjid (musholla), santri, dan pembelajaran kitab kuning. Dengan seiringnya perkembangan zaman, saat ini terdapat banyak pondok pesantren yang mendirikan lembaga pendidikan formal, seperti sekolah dan madrasah. Pesantren, jika disandingkan dengan lembaga pendidikan yang pernah muncul di Indonesia, merupakan sistem pendidikan tertua saat ini dan dianggap sebagai produk budaya Indonesia yang indigenous. $^{7}$

Adapun Menteri Agama Republik Indonesia menetapkan peraturan nomor 3 tahun 1979 tentang klasifikasi pondok pesantren, yaitu:

1) Pondok Pesantren yang menyelenggarakan pengajaran secara tradisional (sistem wetonan atau sorogan);

2) Pondok Pesantren yang menyelenggarakan pengajaran secara klasikal;

3) Pondok Pesantren yang hanya merupakan asrama, adapun santri belajar di madrasah atau sekolah umum;

\footnotetext{
${ }^{4}$ Zamaksyari Dhofier, Tradisi Pesantren Studi Tentang Pandangan Hidup Kyai, hal.18-19.

5 Mujamil Qomar, Pesantren dari Transformasi Metodologi Menuju Demokratisasi Institusi, Jakarta : Erlangga, hal. 6.

${ }^{6}$ Lihat Peraturan Pemerintah Republik Indonesia Nomor 55 Tahun 2007 Pasal 1 Ayat 4

${ }^{7}$ Sulthon Masyhud, dkk, Manajemen Pondok Pesantren, Jakarta: Diva Pustaka, 2003, hal. 1.
} 
4) Pondok Pesantren yang menyelenggarakan sistem pondok pesantren dan sekaligus sistem sekolah atau madrasah. ${ }^{8}$

Menurut penelusuran sejarah, pada awalnya pondok pesantren merupakan lembaga pendidikan yang menitikberatkan kepada pelajaran agama semata. Lembaga tersebut merupakan adopsi dari lembaga pendidikan yang terdapat di timur tengah. Lembaga pesantren juga mengedepankan pendidikan moral dan berorientasi menjadikan lulusannya sebagai ulama. Di antara tokoh nasional yang merupakan lulusan pesantren, yaitu Hasyim Asy’ari, Ahmad Dahlan, Idham Cholid, dan sebagainya.

\section{1) Kyai}

Menurut asal muasalnya, istilah kyai dalam bahasa jawa digunakan untuk tiga jenis gelar berbeda. 1) gelar kehormatan untuk barang-barang yang dianggap sakti dan kramat; 2) gelar kehormatan bagi orang-orang tua pada umumnya; dan 3) gelar untuk seorang ahli agama Islam atau menjadi pimpinan pesantren. Adapun jenis ketiga merupakan gelar yang dikenal dengan istilah ulama. ${ }^{9}$ Ulama memiliki peranan penting dan strategis dalam membentuk masyarakat yang diridhoi Allah. Ulama berasal dari bahasa Arab 'alima, ya'lamu, alim yang artinya orang yang mengetahui. Kata 'alim bentuk jamaknya adalah 'alimun. Sedangkan ulama adalah bentuk jamak dari 'alim yang merupakan bentuk mubalaghah, memiliki makna orang yang sangat mendalam pengetahuannya. ${ }^{10}$

Secara sederhana dapat dipahami bahwa ulama merupakan seseorang yang sangat menguasai ilmu-ilmu agama Islam, seperti ilmu Al-Qur'an, ilmu Hadis, Fiqh, Tauhid, ilmu bahasa Arab, Tasawuf dan mengajarkannya di lembaga pesantren. Istilah ulama memiliki banyak variatif, ulama di Jawa dan Madura disebut dengan istilah kyai, istilah ajengan di Jawa Barat, tuan guru di Lombok, buya di Sumatera Barat.

\section{2) Pondok}

Ciri khas yang paling utama dari pondok pesantren adalah para santri tinggal bersama dan belajar di pondok dengan bimbingan ustadz dan kyai. Saefudin Zuhri membedakan secara tegas bahwa pondok bukanlah "asrama". Pondok didirikan atas dasar modal gotong royong dari santri yang telah menjadi alumni di pesantren dengan

\footnotetext{
${ }^{8}$ Mahpuddin Noor, Potret Dunia Pesantren, Bandung: Humaniora, 2006, hal. 43.

9 Amin Haedari, dkk. Masa Depan Pesantren dalam Tantangan Modernitas dan Tantangan Kompleksitas Global, Jakarta : IRD Press, 2004, hal. 30.

${ }^{10}$ Hasbi Indra, Pesantren dan Transformasi Sosial (Studi Atas Pemikiran KH. Abdullah Syafi'ie dalam Bidang Pendidikan Islam). Jakarta : Penamadani, 2003, hal. 22.
} 
masyarakat yang masuk ke dalam kategori ekonomi pas-pasan. Hal tersebut menjadikan hubungan kuat antara santri atau masyarakat dengan pesantren karena adanya rasa memiliki pada lembaga pesantren tersebut. Konsep tersebut sangat berbeda dengan konsep asrama dan lembaga pendidikan lainnya. Adapun beberapa sebab yang menjadikan pesantren harus memiliki pondok, adalah: 1) Ketertarikan para santri untuk terus menggali ilmu sang kyai secara langsung hari demi hari dan waktu demi waktu; 2) Lokasi pesantren yang jauh dari keramaian membutuhkan tempat tinggal khusus bagi santri; dan 3) Terciptanya hubungan kekeluargaan antara santri dengan kyai. ${ }^{11}$

Kelebihan sistem pondok menurut hemat penulis adalah agar terciptanya suasana dan kondisi lingkungan belajar yang kondusif, mandiri, bertanggungjawab dan dalam pengawasan 24 jam dari ustadz dan kyai. Hal tersebut juga mendorong munculnya beragam lembaga pendidikan dengan sistem asrama (boarding system) dan mengadopsi sistem pondok pesantren.

\section{3) Masjid}

Tradisi penggunaan masjid sebagai pusat pendidikan Islam dan aktifitas kaum muslim dimulai sejak masa Rasulullah SAW, kemudian diteruskan oleh para sahabat dan khalifah berikutnya. Masjid merupakan pilihan ideal bagi kaum muslim sebagai tempat pertemuan, musyawarah, pusat pendidikan sebelum terdapat madrasah/sekolah, pengajian, dan kegiatan administrasi. ${ }^{12}$ Menurut Abdurahman Wahid, posisi masjid memiliki makna tersendiri bagi kalangan pesantren, yaitu sebagai tempat untuk mendidik santri agar dapat terlepas dari hawa nafsu, sedangkan keberadaannya di tengah-tengah komplek pesantren adalah mengikuti model wayang, yaitu di tengahtengah terdapat pegunungan. Hal ini menunjukkan bahwa nilai-nilai kearifan lokal harus dipertimbangkan untuk dilestarikan oleh pesantren. ${ }^{13}$

\section{4) Santri}

Santri merupakan murid yang mencari ilmu pada lembaga pondok pesantren. Terdapat dua kategori santri, yaitu: 1) santri mukim, yaitu santri dari luar daerah yang

\footnotetext{
${ }^{11}$ Hasbi Indra, Pesantren dan Transformasi Sosial (Studi Atas Pemikiran KH. Abdullah Syafi'ie dalam Bidang Pendidikan Islam), hal. 32.

${ }^{12}$ Abdul Rachman Saleh, Pendidikan Agama dan Keagamaan Visi, Misi dan Aksi, Jakarta : PT. Gemawindu Pancaperkasa, 2000, hal. 112.

${ }^{13}$ Mujamil Qomar, Pesantren dari Transformasi Metodologi Menuju Demokratisasi Institusi, hal. 21 .
} 
hendak bermukim dalam mencari ilmu; dan 2) santri kalong, yaitu santri dari desa-desa di sekitar pesantren, mereka mencari ilmu tanpa tinggal di pondok. ${ }^{14}$

\section{5) Pengajaran Kitab Kuning}

Kitab kuning dapat dimaknai sebagai kitab klasik yang sering dikaji dan dipelajari oleh para santri dan kyai, biasanya kitab-kitab klasik madzhab syafi'i berbahasa Arab. Hal ini merupakan satu-satunya metode yang secara formal diajarkan dalam komunitas pesantren di Indonesia khususnya Jawa dan Madura. Kitab-kitab kuning yang diajarkan pada pondok pesantren dibagi menjadi 8 kelompok : 1) Nahwu dan Sharaf; 2) Fiqh; 3) Ushul Fiqh; 4) Hadis; 5) Tafsir; 6) Tauhid; 7) Tasawuf; dan 8.Tarikh dan Balaghah. ${ }^{15}$

Dalam pengkajian kitab kuning, terdapat dua model, yaitu 1) model sorogan: santri satu persatu secara bergantian mengaji atau membaca kitab tertentu dengan kyai secara langsung. Peran kyai hanya menyimak bacaan santri dengan disertai penjelasan, di sini peran santri harus aktif dalam proses pembelajaran; 2) model bandongan, peran kyai sangat aktif dalam proses pembelajaran dalam model ini, kyai membaca satu kitab disertai dengan penjelasan dengan diikuti oleh santri yang ikut menerjemahkan kitab yang dibaca oleh kyai. Abdurahman Wahid berpendapat bahwa tradisi keilmuan pesantren yang tidak bisa dilepaskan dari pergulatan intelektual yang terjadi sepanjang sejarah berkembang dan meluasnya Islam. ${ }^{16}$

Sistem pendidikan pesantren mempunyai sembilan keunggulan kompetitif dibandingkan dengan sistem pendidikan lainnya, yaitu: 1) Orientasi pendidikan pesantren berupa community based education (pendidikan berbasis komunitas/masyarakat). Pesantren berperan sebagai lembaga pengabdian dan pemberdayaan masyarakat, dan agent of social development (agen pengembangan masyarakat); 2) Keunggulan dan kelebihan visi pendidikan pesantren dalam mengimplementasikan fungsi ibadah kepada Allah dan fungsi khilafah manusia di atas bumi; 3) Pendidikan pesantren memiliki misi umum dalam mempersiapkan sumber daya manusia berkualitas imaniyah, ilmiah, dan 'amaliyah, dan misi khusus dalam mempersiapkan kader-kader pemimpin umat yang memahami agama (mutafaqqih fi al-

\footnotetext{
${ }^{14}$ Zamaksyari Dhofier, Tradisi Pesantren Studi Tentang Pandangan Hidup Kyai, hal. 51-52.

${ }^{15}$ Zamaksyari Dhofier, Tradisi Pesantren Studi Tentang Pandangan Hidup Kyai, hal. 50.

${ }^{16}$ Abdurrahman Wahid, Menggerakkan Tradisi, Esai-esai Pesantren, Yogyakarta : LkiS, hal. 158.
} 
din); 4) Pesantren sejak awal telah menanamkan kepada santrinya niat utama mencari ilmu untuk ibadah kepada Allah SWT; 5) Arah pendidikan di pesantren bersifat vertical ketuhanan dan horizontal kemasyarakatan; ${ }^{17}$ 6) Pendidikan pesantren berorientasi pada kompetensi sesuai dengan obsesi para santri dan kyai, yaitu ilmu nafi' (ilmu yang bermanfaat), dan bukan sekedar content oriented (orientasi isi); 7) Kesesuaian prinsip pendidikan pesantren dengan paradigma manajemen berbasis sekolah dalam prinsip kejuangan, pengorbanan, jihad, dan ijtihad yang dijiwai oleh jiwa keikhlasan, kesederhanaan, percaya diri dan kemandirian, kebersamaan serta kebebasan berpikir yang positif dan produktif; 8) Pimpinan pesantren berfungsi tidak hanya sebagai leader (pemimpin), central figure (figur utama), maupun top manager (manajer utama) saja, namun juga sebagai moral force (kekuatan moral) bagi santri dan seluruh warga pesantren; 9) Pendidikan pesantren tidak sekedar menyelenggarakan pengajaran yang bersifat verbal dan retorik, serta keunggulan-keunggulan lainnya, namun lebih mementingkan kerja-kerja pendidikan, pengasuhan, dan pembudayaan dengan prinsip uswah (keteladanan) dan suhbah (pendampingan). ${ }^{18}$

\section{Sekilas Ma'had Ar-Raayah}

Berkaitan dengan pondok pesantren, penulis telah melakukan sebuah studi ilmiah ke sebuah pondok pesantren di wilayah sukabumi pada desember 2014, yaitu Ma'had Ar-Raayah. Pesantren ini didirikan melalui kerjasama para dermawan asal Arab Saudi. Lima unsur penting pesantren pun sudah dimiliki oleh Ma'had tersebut. Ma'had tersebut dikhususkan untuk peningkatan keterampilan bahasa Arab bagi para santri. Ma'had ini menggunakan model pengelolaan lembaga dan pembelajaran yang unik menurut penulis.

Ma'had Ar-Raayah terletak di dalam sebuah komplek khusus dengan luas beberapa hektar dan steril dari masyarakat luar. Seluruh warga ma'had ini tinggal di dalam komplek tersebut, di antaranya ustadz, santri, petugas administrasi, petugas jasaboga, petugas perkebunan dan peternakan, petugas keamanan, dan sebagainya. Dan hebatnya mereka semua menggunakan bahasa Arab dalam komunikasi sehari-hari.

\footnotetext{
${ }^{17}$ Siswanto, "Madrasah Unggulan Berbasis Pesantren", Ulumuna : Jurnal Studi Keislaman, Vol. 18, No. 1, 2014, hal. 165. $81-83$.

${ }^{18}$ Mohammad Tidjani Djauhari, Masa Depan Pesantren, Agenda yang Belum Terselesaikan, hal.
} 
Para santri di ma'had ini dibebaskan dari biaya pendidikan atau gratis sama sekali. Selain itu, mereka mendapatkan juga buku pelajaran dan makan tiap hari secara cuma-cuma. Hal ini terjadi karena dana dari hasil derma dari para dermawan Arab digunakan juga untuk pengelolaan perkebunan dan peternakan milik ma'had. Sehingga semua sumber pokok makanan sehari bisa mereka hasilkan secara mandiri.

Dalam kegiatan seleksi masuk santri pun menggunakan model yang unik. Jika pondok pesantren pada umumnya menyeleksi siswa berdasarkan tingkat wawasan yang dimiliki, maka di ma'had ini para calon santri diseleksi hanya berdasarkan besarnya minat mereka belajar agama Islam dan bahasa Arab. Mayoritas santri memiliki latar belakang pendidikan dari lembaga pendidikan umum, baik SMA maupun SMK. Adapun ma'had ini memiliki lembaga pendidikan formal jenjang pendidikan tinggi, yaitu Sekolah Tinggi Ilmu Bahasa Arab (STIBA) Ar-Raayah. Jadi, para santri mempelajari ilmu agama dan bahasa Arab di ma'had, sedangkan mereka mempelajari ilmu pendidikan formal di sekolah tinggi. Tenaga Pengajar Ma'had Ar-Raayah mayoritas merupakan alumni dari pendidikan S1 LIPIA Jakarta, sedangkan pengajar STIBA Ar-Raayah merupakan alumni dari pendidikan S2 dan S3 dari berbagai universitas di dalam dan luar negeri.

\section{Sekolah}

Ketika Belanda mulai menjajah Indonesia dengan mengambil semua kekayaan dan rempah-rempah di wilayah Indonesia, Belanda juga melakukan penjajahan terhadap dunia pendidikan yang sebelumnya dilakukan oleh warga pribumi di tempat-tempat ibadah dan pondok pesantren. Penjajahan tersebut dilakukan dengan membentuk lembaga pendidikan baru yang dinamakan Sekolah.

Pada tanggal 8 Maret 1819, Gubernur Belanda Jenderal Vander Capellen beserta jajarannya mengadakan penelitian tentang pendidikan masyarakat jawa dengan tujuan untuk meningkatkan kemampuan membaca dan menulis di kalangan mereka. Dengan hasil penelitain tersebut diharapkan pelaksanaan undang-undang dan peraturan pendidikan dapat diperbaiki. Selain itu, kebutuhan guru untuk diberikan motivasi melalui peraturan yang sesuai juga diteliti. ${ }^{19}$

Satu abad kemudian, di Minahasa dan Maluku berdiri sekolah zending. Sekolah ini mendapatkan subsidi dari pemerintah Belanda yang tidak memperhatikan pendidikan hal. 1.

\footnotetext{
${ }^{19}$ Karel A. Steenbrink, Pesantren, Madrasah, Sekolah, Pendidikan Islam dalam Kurun Modern,
} 
pribumi yang sudah tumbuh di masyarakat. Sekolah ini memusatkan diri pada pendidikan agama Kristen. Tahap awal yang dilakukan oleh pihak sekolah tersebut adalah menerjemahkan kitab injil ke dalam bahasa Melayu dengan harapan masyarakat setempat dapat memiliki kemampuan dalam membaca dan menulis. ${ }^{20}$ Selain itu, sekolah tersebut juga mengajarkan ilmu bumi, ilmu sejarah dan ilmu musik dengan sebagian besar mengisahkan perjalanan Rasul Paulus, sejarah injil, dan musik gereja.

Pada tahun 1867, sesuai dengan instruksi Gubernur Van der Chijs sekolah zending kemudian masuk kedalam sistem pendidikan umum gubernemen (sekolah umum). Masuknya sekolah zending ke dalam sistem sekolah umum lebih mudah dibandingkan dengan Pondok Pesantren karena para muridnya telah terbiasa dengan tulisan latin dan mampu berkomunikasi dengan bahasa Melayu. Bahasa Melayu merupakan bahasa komunikasi sehari-hari pada lingkungan gubernemen. ${ }^{21}$

Pendidikan formal di Indonesia mulai dikenal pada masa penjajahan, namun pada awalnya sekolah formal masih dikhususkan bagi warga Belanda di Hindia Belanda. Di antara sekolah yang terdapat pada saat itu, adalah sebagai berikut:

1. ELS (Eurospeesch Lagere School) atau disebut juga HIS (Hollandsch Inlandsch School) sekolah dasar dengan lama studi sekitar 7 tahun. Sekolah ini menggonakan sistem dan metode seperti sekolah di negeri belanda;

2. HBS (Hogere Burger School) yang merupakan sekolah lanjutan tinggi pertama untuk warga negara pribumi dengan lama belajar 5 tahun. AMS (Algemeen Metddelbare School) mirip HBS, namun setingkat SLTA/SMA. Sekolah Bumi Putera (Inlandsch School) dengan bahasa pengantar belajarnya adalah bahasa daerah dan lama studi selama 5 tahun.

3. Sekolah Desa (Volksch School) dengan bahasa pengantar belajar bahasa daerah sekitar dan lama belajar adalah 3 tahun.

4. Sekolah lanjutan untuk sekolah desa (Vervolksch School) belajar dengan bahasa pengantarnya bahasa daerah dan masa belajar selama 2 tahun.

\footnotetext{
${ }^{20}$ Karel A. Steenbrink, Pesantren, Madrasah, Sekolah, Pendidikan Islam dalam Kurun Modern, hal. 3.

${ }^{21}$ Karel A. Steenbrink, Pesantren, Madrasah, Sekolah, Pendidikan Islam dalam Kurun Modern, hal. 4-5.
} 
5. Sekolah Peralihan (Schakel School) yaitu sekolah lanjutan untuk sekolah desa dengan lama belajar 5 tahun dan berbahasa belanda dalam kegiatan belajar mengajar.

6. MULO Sekolah lanjutan tingkat pertama singkatan dari Meer Uitgebreid Lager Onderwijs dengan tingkatan yang sama dengan SMP pada saat jika dibandingkan dengan masa kini.

Menurut penelusuran sejarah, sekolah merupakan lembaga pendidikan yang menitikberatkan kepada pelajaran umum semata. Lembaga tersebut merupakan adopsi dari lembaga pendidikan yang terdapat di negara barat. sekolah juga mengedepankan pendidikan sains dan intelektual siswa. Di antara tokoh nasional yang merupakan lulusan sekolah, yaitu Soetomo, Ki Hajar Dewantara, dan Jenderal Soedirman.

Selain itu, muncul dikotomi antara pesantren dan sekolah seperti yang dikabarkan pada Berita Tahoenan Hindia Timur / Weltevreden, landedrukkerij 1927. Para santri memandang priyayi dan abangan sebagai kafir karena meniru perilaku kaum kafir Belanda, sedangkan Para priyayi memandang rendah santri. Yang hanya belajar agama semata (hanya persoalan ibadah).

Pemerintah dalam rangka menyelesaikan masalah yang muncul karena dikotomi tersebut berupaya untuk memberikan jalan tengah kepada lembaga pesantren dan sekolah. Pemerintah memberikan solusi berupa model perpaduan lembaga pendidikan, yaitu madrasah sebagai lembaga pendidikan yang berorientasi pada ilmu agama, moral, dan sains yang bertujuan menghasilkan ulama yang intelek, seperti M. Quraish Shihab. Juga sekolah Islam yang berorientasi pada ilmu sains, moral, dan ilmu agama yang bertujuan menghasilkan intelek yang 'alim, seperti BJ Habibie.

Setelah Indonesia merdeka, dengan gagasan dan keyakinan yang dilandasi semangat perjuangan Proklamasi Kemerdekaan serta wawasan ke masa depan, Pemerintah Indonesia meresmikan berdirinya Sekolah Indonesia pada tanggal 2 Maret 1959. Sekolah Indonesia lahir dalam suasana penuh dinamika dalam rangka mengemban misi pengabdian ilmu pengetahuan dan teknologi, yang berpijak pada kehidupan nyata di bumi sendiri bagi kehidupan dan pembangunan bangsa yang maju dan bermartabat.

Setelah itu, dalam konteks Islam, modernisasi pendidikan Islam mulai menemukan momentum. Pendidikan direalisasikan dengan pendirian lembaga-lembaga 
pendidikan modern dalam rangka modernisasi sistem pendidikan Islam. Perkembangan mencolok terjadi pada tahun 90-an dengan munculnya sekolah-sekolah Islam elite Muslim yang dikenal sebagai "sekolah Islam". Sekolah-sekolah itu mulai menyatakan diri secara formal dan diakui oleh kalangan muslim sebagai "sekolah unggulan" atau sekolah Islam unggulan. Sekolah Islam unggulan tersebut seakan menjawab tuntutan modernisasi sistem pendidikan Islam.

Sekolah-sekolah tersebut dapat dikatakan sebagai sekolah unggulan Islam dikarenakan beberapa hal yang mendasarinya. Alasan yang melatar belakangi sekolahsekolah tersebut bersifat elite antara lain dari segi akademis. Dalam beberapa kasus, hanya siswa-siswa yang terbaik saja yang dapat diterima. Sedangkan para guru yang mengajar pun hanyalah mereka yang memenuhi kualifikasi yang dipersyaratkan melalui seleksi yang kompetitif. Sekolah-sekolah tersebut dikelola oleh manajemen yang baik dengan berbagai fasilitas yang memadai dan lengkap seperti perpustakaan, ruang komputer, masjid dan sarana olahraga.

Sekolah Islam termasuk sekolah Islam terpadu, memasukkan nilai-nilai Islam dari berbagai aspek. Baik aspek formal melalui pembelajaran agama, maupun semua mata pelajaran, seperti IPA, Matematika, Geografi, yang harus dikaitkan dengan nilainilai spritual, nilai-nilai Illahiah. Adapun seleksi tenaga pengajar dilakukan dengan merekrut guru-guru yang memiliki visi dan ideologi yang sama. Mereka tidak diperkenankan merokok, berakhlak mulia, dan bisa menjadi teladan. Selain itu, perilaku ibadah anak-anak juga dibentuk melalui shalat atau doa-doa dengan mengikuti sunnah. Dengan fenomena tersebut, pemerintah dan praktisi pendidikan mulai percaya akan kualitas yang ditawarkan oleh sekolah Islam unggulan. Hal tersebut memungkinkan penyempitan perbedaan (dikotomi) antara pendidikan Islam dan pendidikan umum dalam lingkup pendidikan nasional. Pendidikan Islam harus diberikan kesempatan untuk meningkatkan kualitas untuk mewujudkan pendidikan bermutu sejajar dengan pendidikan umum. ${ }^{22}$

\section{Sekilas Sekolah Islam Cikal Harapan}

Berkaitan dengan sekolah, penulis pernah melakukan wawancara dengan koordinator PKBM di Tangerang Selatan yang juga sebagai kepala madrasah di wilayah Ciater. Di wilayah BSD terdapat sekolah islam yang terletak di antara dua sekolah

${ }^{22}$ Arief Efendi, "Peran Strategis Lembaga Pendidikan Berbasis Islam di Indonesia", El-Tarbawi: Jurnal Pendidikan Islam, Vol. 1, No. 1, 2008, hal. 7-8. 
katolik, yaitu Sekolah Islam Cikal Harapan, Saint John School, dan Sekolah Stella Maris.

Penulis mendapati informasi unik terkait ketiga sekolah tersebut. Dari segi biaya pendidikan, hanya siswa yang berasal dari kalangan atas yang dapat melanjutkan studi ke Sekolah Islam Cikal Harapan. Hal ini menyebabkan calon siswa yang berasal dari kalangan menengah ke bawah tidak merasakan pendidikan yang diselenggarakan oleh sekolah tersebut.

Hal yang disayangkan adalah kedua sekolah bernotabene sekolah katolik yang terdapat di satu lingkungan yang sama memberikan beastudi secara penuh kepada calon siswa dengan latar belakang agama Islam. Maka tidak sedikit siswa di sekolah tersebut yang berasal dari dari keluarga muslim. Hal yang sangat dikhawatirkan apabila siswasiswa tersebut terjebak kepada politik balas budi yang disampaikan para kaum misionaris. Bisa jadi mereka tertarik untuk berpindah keyakinan dan keluar dari agama Islam.Namun, perlu diadakan pengecekan lebih lanjut terkait tersedianya tempat pelaksanaan ibadah bagi para siswa yang memiliki keyakinan berbeda dengan siswa pada umumnya di sekolah tersebut dan juga tersedianya guru agama untuk siswa minoritas. Hal tersebut harus sangat diperhatikan karena setiap peserta didik pada satuan pendidikan di semua jalur, jenjang, dan jenis pendidikan berhak mendapat pendidikan agama sesuai agama yang dianutnya dan diajar oleh pendidik yang seagama. ${ }^{23}$

\section{Madrasah}

Madrasah dalam pendidikan di Indonesia bukanlah merupakan lembaga asli pribumi. Kata "madrasah" sendiri berasal dari bahasa Arab yang memiliki makna "sekolah". Kata "sekolah" pun berasal dari bahasa Inggris yaitu "school atau scola" yang pada akhirnya dibakukan menjadi bahasa Indonesia. ${ }^{24}$ Madrasah merupakan lembaga pendidikan yang menyelenggarakan proses pembelajaran secara formal tidak berbeda dengan sekolah namun berbeda dalam lingkup budaya dengan menitikberatkan pendidikannya bernuansa agama. Madrasah sebagai sekolah keagamaan lambat laun mengalami perubahan seiring perkembangan zaman dengan mulai menambah materi pelajaran umum dengan tetap memegang teguh budaya Islam. ${ }^{25}$

\footnotetext{
${ }^{23}$ Lihat Peraturan Pemerintah Republik Indonesia Nomor 55 Tahun 2007 tentang Pendidikan Agama dan Pendidikan Keagamaan Pasal 4 Ayat 1-6.

${ }^{24}$ A. Malik Fadjar, Madrasah dan Tantangan Modernitas, Bandung: Mizan, 1999, hal. 18.

${ }^{25}$ A. Malik Fadjar, Madrasah dan Tantangan Modernitas, hal. 19. Lihat juga Peraturan Menteri Agama RI Nomor 90 Tahun 2013 tentang Penyelenggaraan Pendidikan Madrasah Pasal 1 ayat 2.
} 
Sejatinya madrasah dengan pondok pesantren memiliki satu model dan tujuan yang sama dalam proses pembelajaran. Madrasah merupakan pengembangan pendidikan dari pondok pesantren yang memiliki misi untuk mencerdaskan anak bangsa yang pada saat itu belum berkeinginan untuk tinggal di pondok dalam proses belajarnya. Hal ini dapat dilihat dari penggagas dan pendiri awal madrasah yang mayoritas adalah para ulama yang juga menjadi pendiri pondok pesantren, di antaranya Syekh Amrullah Ahmad (1907) di Padang, KH. Ahmad Dahlan (1912) di Yogyakarta, KH Wahab Hasbullah dan KH Mansyur (1914), dan KH. Hasyim Asy'ari yang pada tahun 1919 mendirikan Madrasah Salafiyah di Tebuireng Jombang. ${ }^{26}$

Madrasah lahir pada awal abad ke-20 yang merupakan periode pertumbuhan madrasah dalam catatan sejarah pendidikan Islam di tanah air. ${ }^{27}$ Pada masa tersebut, kaum muslim tanah menyadari bahwa mereka tidak dapat bersaing dengan kekuatan kolonialis Belanda jika hanya mengandalkan cara-cara tradisional dalam membela tanah air dan menegakkan ajaran Islam. Kesadaran tersebut muncul juga berkat peranan alumni pendidikan di Timur Tengah yang kembali ke tanah air dan mengembangkan pendidikan madrasah dengan pengembangan metode dan kurikulum. ${ }^{28}$

Muncul madrasah memiliki dua alasan, yaitu 1) Adanya pembaruan pendidikan Islam di Indonesia; dan 2) Adanya respon pendidikan Islam terhadap kebijakan pendidikan kolonial. ${ }^{29}$ Munculnya madrasah terkesan juga sebagai kritik pada lembaga pendidikan pondok pesantren. Madrasah merupakan usaha pembaruan dan menjembatani hubungan antara sistem tradisional (pesantren) dengan sistem pendidikan modern juga sebagai upaya penyempurnaan sistem pendidikan pondok pesantren agar lulusannya memperoleh kesempatan yang tidak berbeda dengan sekolah yang umum. Dan akhirnya banyak bermunculan madrasah di lingkungan pondok pesantren. ${ }^{30}$

Setelah terbit UU Sisdiknas No. 4 tahun 1950 jo No. 12 tahun 1954 pasal 2 ayat 1 dan 2 yang menyatakan bahwa pendidikan dan pengajaran di sekolah-sekolah agama tidak diatur dalam uu, dan akan diatur dalam undang-undang lain, muncul persoalan

\footnotetext{
${ }^{26}$ Abdul Rachman Saleh, Pendidikan Agama dan Keagamaan Visi, Misi, dan Aksi, Jakarta : PT. Gemawindu Pancaperkasa, 2000, hal. 112.

${ }^{27}$ Maksum, Madrasah : Sejarah dan Perkembangannya, Jakarta : Logos Wacana Ilmu, 1999, hal. 98.

${ }^{28}$ Mahmud Arif, Panorama Pendidikan Islam di Indonesia, Yogyakarta: Idea Press, 2009, hal. 71.

${ }^{29}$ Maksum, Madrasah : Sejarah dan Perkembangannya, hal. 82.

${ }^{30}$ A. Mukti Ali, Metode Memahami Agama Islam, Jakarta : Bulan Bintang, 1991, hal. 11-12.
} 
tentang lembaga pendidikan Islam yang masih berada di luar sistem pendidikan nasional. hal ini berarti madrasah dan pesantren telah terdiskriminasi dari sekolah pada sisi pengakuan, penghargaan, dan perlakuan dalam bentuk lulusan, melanjutkan studi, lapangan kerja, dana, dan fasilitas. Di antara penyebabnya, yaitu: 1) pengaruh pandangan belanda terhadap pesantren dan madrasah; 2) tampilan pesantren dan madrasah belum sejajar dengan sekolah; dan 3) sikap aneh, mengakui sebagai wajib belajar (bias).

Dampak yang diterima oleh lembaga pendidikan Islam setelah tidak masuk ke dalam sistem pendidikan nasional, di antaranya pesantren dan madrasah menjadi tidak berdaya sehingga mengakibatkan mutu pendidikannya menurun, kuantitas siswa menurun, dan lembaga tersebut dianggap menjadi sekolah kelas dua atau sekolah pinggiran. Terlebih lagi muncul sikap diskriminatif pemerintah terhadap madrasah dan pesantren. Keppres 34/1972 dan Inpres 15/1974 ini dianggap melemahkan dan mengasingkan madrasah dari pendidikan nasional.

Barulah setelah terbitnya SKB 3 Menteri tahun 1975 yang memberikan pengakuan eksistensi madrasah yang sejajar dengan sekolah-sekolah umum dan memberikan kepastian yang mengarah pada pembentukan sistem pendidikan nasional yang integratif, berikut penjelasannya:

1. Madrasah meliputi 3 tingkatan: MI setingkat dengan SD, MTs setingkat dengan SMP, dan MA setingkat dengan SMA

2. Ijazah madrasah dinilai sama dengan ijazah sekolah umum yang sederajat.

3. Lulusan madrasah dapat melanjutkan ke sekolah umum yang setingkat lebih atas.

4. Siswa madrasah dapat berpindah ke sekolah umum yang setingkat.

Madrasah melalui SKB ini terintegrasi ke dalam sistem pendidikan nasional yang setara dengan sekolah umum meskipun pengelolaannya tetap berada ada Departemen Agama. Dari segi organisasi, madrasah sama dengan sekolah umum; dari segi jenjang pendidikan, MI, MTs dan MA sederajat dengan SD, SMP dan SMA; dari segi muatan mata pelajaran, murid-murid madrasah pun memperoleh pengajaran pengetahuan umum yang sama pula. Hal ini bermakna terjadinya MOBILITAS sosial dan vertikal siswa-siswa madrasah dan TERBUKANYA peluang anak-anak santri memasuki wilayah pekerjaan pada sektor modern. Namun kurikulum madrasah berubah 
drastis dari pelajaran agama sebanyak $70 \%$ dan pelajaran umum sebanyak 30\%, menjadi pelajaran umum sebanyak $70 \%$ dan pelajaran agama sebanyak $30 \%$. Hal ini tidak cukup memadai bagi alumni MA untuk memasuki IAIN, apalagi menjadi calon-calon ulama.

Dampak yang kurang baik SKB ini adalah tamatan Madrasah Aliyah (MA) menjadi lebih siap masuk ke perguruan tinggi umum daripada perguruan tinggi agama. Penguasaan agama tamatan MA bukan hanya sangat lemah, lebih dari itu bahkan tidak dapat diandalkan untuk menjadi calon-calon ulama. Alasan ini yang melatarbelakangi Munawir Syadzali, Menteri Agama (1983-1993), mengeluarkan KepMenag No. 73 tahun 1987 mendirikan MAPK (madrasah Aliyah Program Khusus yang meyiapkan calon-calon ulama dengan kurikulum $70 \%$ agama dan $30 \%$ umum.

Dalam perkembanganya model madrasah diistilahkan sebagai Madrasah Berbasis Pesantren. ${ }^{31}$ Banyak bermunculannya madrasah di lingkungan pesantren nyatanya tidak menghapus tradisi pesantren yang sudah ada dan bertahan lama, misalnya tradisi-tradisi keagamaan, tradisi intelektual, dan tradisi kepemimpinan khas pesantren masih sering ditemukan pada madrasah di lingkungan pesantren. ${ }^{32}$ Pertumbuhan madrasah menjadi indikator penting bagi kemajuan prestasi budaya kaum muslimin yang mencerminkan keunggulan capaian keilmuan, intelektual dan kultural yang mewujudkan kebanggaan terhadap madrasah. Selain itu, madrasah menjadi media untuk tercapainya dinamika intelektual-keagamaan.

Setelah melewati sejarah panjang yang penuh dinamika, pada akhirnya madrasah semakin mendapatkan tempat dan pengakuan dari pemerintah. Undang-undang sisdiknas tahun 2003 telah semakin mempertegas posisi dan kedudukan madrasah yang setara dengan sekolah umum lainnya. Oleh karena itu, masyarakat ataupun pemerintah seharusnya tidak bisa lagi mendikotomikan antara sekolah umum dengan sekolah agama.

Memang semakin banyak pesantren yang mendirikan madrasah. Pada 2009, terdapat 2072 pesantren yang memiliki Madrasah Ibtidaiyah, 2721 pesantren yang memiliki Madrasah Tsanawiyah, 224 pesantren yang memiliki Madrasah Tsanawiyah terbuka,

\footnotetext{
${ }^{31}$ Mahmud Arif, Panorama Pendidikan Islam di Indonesia, Yogyakarta: Idea Press, 2009, hal. 89.

32 Karel A. Steenbrink, Pesantren Madrasah Sekolah, Pendidika Islam dalam Kurun Modern, Jakarta : LP3ES, 1994, hal. 220.
} 
1580 pesantren yang memiliki Madrasah Aliyh, 35 pesantren yang memiliki Madrasah Keterampilan, dan 176 pesantren yang memiliki Madrasah Aliyah Keagamaan. ${ }^{33}$

Dewasa ini, pemberdayaan madrasah merupakan hal yang sangat penting dilakukan pada era otonomi daerah, era otonomi pendidikan. Terdapat beberapa madrasah yang sudah masuk kategori madrasah unggulan, seperti Madrasah Pembangunan UIN Jakarta, MAN 4 Jakarta, MIN Malang, MAN Insan Cendekia, dan lain sebagainya, yang ternyata bisa bersaing dan berkompetisi dengan sekolah yang berada di bawah naungan Kemendikdasmen. Hal tersebut menunjukkan aspek manajemen suatu lembaga pendidikan termasuk juga madrasah akan sangat menentukan keberhasilan suatu lembaga pendidikan. Uang hanya sebagai salah satu faktor dan bukan satu-satunya faktor. Selain itu, perlu kesabaran secara bertahap dalam rangka penyamaan derajat, penyamaan perlakuan dengan sekolah di bawah naungan Kemendikdasmen, karena madrasah dengan sejarah panjangnya sudah dianggap bagian dari sistem pendidikan nasional. Pada akhirnya kemajuan madrasah bukan terletak pada apakah berada di bawah naungan Kemenag ataupun Kemendikdasmen, namun terletak pada kreativitas pengelola madrasah dalam berbenah diri. Secara umum meski madrasah dalam pencapaian aspek kognitif semisal nilai UN bisa jadi lebih rendah dari sekolah di bawah naungan Kemendikdasmen, namun pada aspek pengembangan mental, karakter, spiritual, madrasah lebih tinggi dari sekolah di bawah naungan Kemendikdasmen. ${ }^{34}$

Berbicara mengenai madrasah unggulan, terdapat beberapa karakteristik yang hendak dimiliki oleh sebah madrasah unggulan, di antaranya:

1) Dari segi input, madrasah unggulan memiliki kebijakan, tujuan, dan sasaran mutu yang jelas, adanya sumber daya yang tersedia dan siap, staf yang kompeten dan berdedikasi tinggi, memiliki harapan prestasi tinggi, fokus pada pelanggan (khususnya siswa) dan adanya input manajemen, yang ditandai dengan tugas yang jelas, rencana rinci dan sistematis, program yang mendukung pelaksanaan rencana dan sistem pengendali mutu yang efektif.

\footnotetext{
${ }^{33}$ Mujamil Qomar, Pesantren, dari Transformasi Metodologi menuju Demokratisasi Institusi, Jakarta: Erlangga, 2008, h. 94.

${ }^{34}$ M. Daud Yahya, "Posisi Madrasah dalam SIstem Pendidikan Nasional di Era Otonomi Daerah”. Jurnal Khazanah Vol. XII, No. 1, 2014, hal. 99-100. Lihat juga Azkia Muharom Albantani, "Preparing The Future Leaders Through Character Education", Proceeding: The $2^{\text {nd }}$ ICEMS 2015, hal. 393. Lihat juga Azkia Muharom Albantani, "Pendidikan Karakter Menyongsong Indonesia Emas 2045", Prosiding Seminar Nasional : Professional Learning untuk Indonesia Emas 2015, hal. 454-457.
} 
2) Dari aspek output, madrasah unggulan memperoleh banyak prestasi akademik yang ditunjukkan dengan nilai UN, lomba karya ilmiah, lomba mata pelajaran, serta prestasi nonakademik ditunjukkan dengan keingintahuan yang tinggi, kerja sama yang baik, toleransi, kedisiplinan, kerajinan, prestasi olahraga dan seni.

3) Dari aspek proses, madrasah unggulan menyelenggarakan proses pembelajaran efektif, kepemimpinan kepala madrasah yang kuat, lingkungan yang aman dan tertib, pengelolaan tenaga kependidikan yang efektif, memiliki budaya mutu, memiliki team work kompak, cerdas, dan dinamis, memiliki kemandirian, adanya partisipasi yang tinggi dari masyarakat, mempunyai keterbukaan, mempunyai kemauan untuk berubah baik psikologis maupun fisik, melakukan evaluasi dan perbaikan secara berkelanjutan, responsif dan antisipatif terhadap kebutuhan, mempunyai komunikasi yang baik, mempunyai akuntabilitas, memiliki dan menjaga sustainabilitas dalam program dan pendanaan. ${ }^{35}$

4) Dalam konteks pendidikan Islam di Indonesia, madrasah unggulan harus mengedepankan keagungan akhlak dan keluhuran budi, terciptanya budaya religius di sekolah, integrasi antara wawasan agama dan umum dalam proses pembelajaran, dan pengembangan kognitif, kepribadian dan spiritual siswa secara integratif dan menyeluruh. $^{36}$

\section{Sekilas MAN 4 Jakarta}

Di antara madrasah yang dapat dibanggakan oleh umat muslim ibukota, adalah MAN 4 Jakarta. Penulis akan sekilas mendeskripsikan madrasah tersebut meliputi kelebihan-kelebihannya. Awalnya madrasah ini memiliki identitas MAN 4 Model Jakarta, kemudian diubah menjadi MAN 4 RMBI (Rintisan Madrasah Bertaraf Internasional), dan saat ini berganti nama menjadi MAN 4 Jakarta. Madrasah ini tak jarang dijuluki sebagai miniatur UIN Jakarta, selain tidak sedikit alumninya yang melanjutkan studi jenjang sarjana ke kampus tersebut, madrasah ini pun memiliki banyak wadah kegiatan ekstrakurikuler yang wajib diikuti oleh para siswa, di antaranya KIR (Kelompok Ilmiah Remaja), COLSTRA (Kolaborasi Seni Tradisional), Rohis

\footnotetext{
35 Muhaimin, Pemikiran dan Aktualisasi Pengembangan Pendidikan Islam, Jakarta: RajaGrafindo Persada, 2011, 104-105.

${ }^{36}$ Agus Maimun dan Agus Zaenul Fitri, Madrasah Unggulan, Lembaga Alternatif di Era Kompetitif, Malang: UIN Maliki Press, 2010, hal. 46.
} 
(Rohani Islam), Gempala (Pecinta Alam), Marawis, Arabic Club, ECC (English Club), dan Tari Tradisional.

Tak hanya banyak, kegiatan-kegiatan ekstra tersebut sering memberikan sumbangan piala untuk madrasah melalui perebutan juara di berbagai bidang dan kegiatan, misalnya juara cerdas cermat, pidato, paskibra, rekayasa teknologi, tari tradisional, kejuaraan menyanyi tingkat SMA/MA, dan banyak lagi yang lainnya. Selain itu, tidak sedikit alumninya yang dapat melanjutkan studi sarjana ke luar negeri, seperti Malaysia, Turki, Jepang, dan lainnya melalui jalur beasiswa dan mandiri.

Nilai-nilai pendidikan Islam pun sangat kental ditanamkan dalam proses pembelajaran. Tadarrus Al-Quran merupakan kegiatan rutin bagi siswa sebelum memulai kegiatan belajar. Adapun sanksi yang diberikan kepada siswa terlambat adalah siswa harus melaksanakan shalat dhuha dan menghafal beberapa surat pendek. Selain itu, guru yang terlambat pun mendapatkan sanksi tidak bisa langsung masuk ke lingkungan sekolah. Guru tersebut harus menunggu terlebih dahulu di area luar sekolah sampai dengan izin masuk diberikan. Dengan begitu, penanaman nilai disiplin begitu kental diterapkan. Pada masa sekarang, madrasah ini telah memiliki asrama bernuansa pesantren. Namun tidak semua siswa tinggal di asrama, hanya siswa dari daerah yang banyak tinggal di asrama. Asrama tersebut memiliki pembina yang bertugas membimbing dan mengawasi kegiatan keasramaan rutin.

\section{Kesimpulan}

Pondok pesantren, madrasah, dan sekolah adalah instansi pendidikan yang mempunyai tujuan sama namun berbeda dalam pengelolaannya dan mempunyai karakteristik masing-masing. Peran dan keberadaan pondok pesantren sebagai salah satu lembaga pendidikan asli Indonesia memang harus tetap dilestarikan dan diperhatikan perkembangannya, karena kehadiran pondok pesantren untuk memberdayakan masyarakat dan juga sebagai wadah untuk menyiapkan kader-kader Ulama yang mampu menguasai dan memahami Al-Qur'an dan Hadis secara baik dan benar dan sesuai dengan kebutuhan masyarakat.

Adanya madrasah dipandang menjadi indikator penting bagi perkembangan positif kemajuan prestasi budaya kaum muslimin. Fenomena madrasah yang sedemikian maju adalah cerminan dari keunggulan capaian keilmuan, intelektual dan kultural yang menimbulkan kebanggaan terhadap madrasah. Pendidikan formal di Indonesia mulai 
dikenal pada masa penjajahan. Adapan sekolah berasaskan Islam atau Sekolah Islam Unggulan belakangan muncul dengan karakteristik nilai-nilai integrasi akhlak mulia yang ditanamkan ke semua materi pelajaran.

Hemat penulis, dalam mewujudkan lembaga pendidikan Islam yang bermutu, lembaga tersebut harus tetap mempertahankan nilai-nilai khas yang dimiliki dengan tetap menyelenggarakan pendidikan Islam sesuai dengan acuan Standar Nasional Pendidikan, meliputi standar isi, standar proses, standar kompetensi lulusan, standar pendidik dan tenaga kependidikan, standar sarana dan prasarana, standar pengelolaan, standar pembiayaan, dan standar penilaian pendidikan.[]

\section{Daftar Pustaka}

Abdullah, Anzar. "Pendidikan Islam Sepanjang Sejarah: Sebuah Kajian Politik Pendidikan di Indonesia". Susurgalur Vol. 1 No. 2, 2013.

Albantani, Azkia Muharom. "Preparing The Future Leaders Through Character Education", Proceeding: The $2^{\text {nd }}$ ICEMS 2015.

Albantani, Azkia Muharom. "Pendidikan Karakter Menyongsong Indonesia Emas 2045”, Prosiding Seminar Nasional : Professional Learning untuk Indonesia Emas 2015.

Irfani, Fahmi. Potret Pendidikan Islam di Masa Klasik (Dinasti Abbasiyah dan Ummayah). Jurnal Fikrah Vol 7. No 12016

Ali, A. Mukti. Metode Memahami Agama Islam, Jakarta : Bulan Bintang, 1991.

Arif, Mahmud. Panorama Pendidikan Islam di Indonesia, Yogyakarta: Idea Press, 2009.

Dhofier, Zamaksyari. Tradisi Pesantren Studi Tentang Pandangan Hidup Kyai, Jakarta : LP3ES, Cet.III, 1982.

Djauhari, Mohammad Tidjani. Masa Depan Pesantren, Agenda yang Belum Terselesaikan.

Efendi, Arief. "Peran Strategis Lembaga Pendidikan Berbasis Islam di Indonesia", ElTarbawi: Jurnal Pendidikan Islam, Vol. 1, No. 1, 2008.

Fadjar, A. Malik. Madrasah dan Tantangan Modernitas, Bandung: Mizan, 1999.

Haedari, Amin. dkk. Masa Depan Pesantren dalam Tantangan Modernitas dan Tantangan Kompleksitas Global, Jakarta : IRD Press, 2004.

Indra, Hasbi. Pesantren dan Transformasi Sosial (Studi Atas Pemikiran KH. Abdullah Syafi'ie dalam Bidang Pendidikan Islam. Jakarta : Penamadani, 2003.

Maimun, Agus. Agus Zaenul Fitri, Madrasah Unggulan, Lembaga Alternatif di Era Kompetitif, Malang: UIN Maliki Press, 2010.

Maksum, Madrasah : Sejarah dan Perkembangannya, Jakarta : Logos Wacana Ilmu, 1999. 
Masyhud, Sulthon. dkk, Manajemen Pondok Pesantren, Jakarta: Diva Pustaka, 2003.

Muhaimin, Pemikiran dan Aktualisasi Pengembangan Pendidikan Islam, Jakarta: RajaGrafindo Persada, 2011.

Noor, Mahpuddin. Potret Dunia Pesantren, Bandung: Humaniora, 2006.

Peraturan Pemerintah Republik Indonesia Nomor 55 Tahun 2007 tentang Pendidikan Agama dan Pendidikan Kegamaan.

Peraturan Menteri Agama RI Nomor 90 Tahun 2013 tentang Penyelenggaraan Pendidikan Madrasah

Qomar, Mujamil. Pesantren, dari Transformasi Metodologi menuju Demokratisasi Institusi, Jakarta: Erlangga, 2008.

Saleh, Abdul Rachman. Pendidikan Agama dan Keagamaan Visi, Misi dan Aksi, Jakarta : PT. Gemawindu Pancaperkasa, 2000.

Siswanto, "Madrasah Unggulan Berbasis Pesantren", Ulumuna : Jurnal Studi Keislaman, Vol. 18, No. 1, 2014.

Steenbrink, Karel A. Pesantren, Madrasah, Sekolah, Pendidikan Islam dalam Kurun Modern, Jakarta : LP3ES, 1994.

Wahid, Abdurrahman. Menggerakkan Tradisi, Esai-esai Pesantren, Yogyakarta : LkiS.

Yahya, M. Daud. "Posisi Madrasah dalam SIstem Pendidikan Nasional di Era Otonomi Daerah”. Jurnal Khazanah Vol. XII, No. 1, 2014. 